DOI: 10.17707/AgricultForest.65.4.09

\author{
Serban CHIVULESCU, Stefan LECA*, \\ Albert CICEU, Diana PITAR, Bogdan APOSTOL ${ }^{1}$
}

\title{
PREDICTORS OF WOOD QUALITY OF TREES IN PRIMARY FORESTS IN THE SOUTHERN CARPATHIANS
}

\begin{abstract}
SUMMARY
Functional mechanisms in primary forests can help us discover structural models that can be applied to managed forests. Wood quality is important in silviculture because it influences timber price. Using the structure and tree form of primary forests in the Southern Carpathians as a model, our research objectives were to determine the relationships between wood quality and factors such as coenotic position of trees, the ratio of diameter at breast height (DBH) to tree height, and tree slenderness. Wood quality was strongly related to the coenotic position of trees $(\mathrm{r}=0.89 *-0.99 * * *)$; suppressed (or dominant) trees had higher quality wood than dominant (or suppressed) trees. Wood quality and slenderness were also highly correlated $\left(\mathrm{r}=0.56-0.95^{* * *}\right)$ in most plots - the more slender the tree, the lower its wood quality. We found that trees with the highest quality wood were in the $30-100 \mathrm{~cm}$ DBH range. Therefore, DBH is a reliable predictor of wood quality for uneven-aged forests, providing quick results with little effort.
\end{abstract}

Keywords: Uneven-aged forests, wood quality, Southern Carpathians, primary forests, silvicultural models.

\section{INTRODUCTION}

Primary forests represent one of nature's assets of incalculable value (Bândiu et al. 1995), and are characterised by perfection which cannot be completely imitated by modern silviculture. The virgin forests and uneven aged forest (managed) are understood as stable ecosystems, with a specific equilibrium, from the point of view of structure and composition (Boncina et al. 2014) and provide a continuity of the stand. Concerns about primary ecosystems have increased with the negative effects caused by anthropogenic pressures, such as pollution and logging (Stoiculescu 2013, Curovic et al. 2011). In western part of Europe, because of intensive forest utilisation, most of virgin forests has disappear, but in the Southern Carpathians, large tracts of virgin forest still remain (Reininger 1997, Giurgiu 2013), which need urgent study due to the scientific value they

\footnotetext{
${ }^{1}$ Șerban Chivulescu, Ștefan Leca (corresponding author: stefan.leca@icas.ro), Albert Ciceu, Diana Pitar, Bogdan Apostol, National Institute for Research and Development "Marin Drăcea", Voluntari, ROMANIA

Notes: The authors declare that they have no conflicts of interest. Authorship Form signed online.
} 
have through the lack of human activities (Curovic et al 2013). The aim of such research should be to develop our understanding of primary forest structure, and to apply this knowledge in practice for managing protected areas covered by forests and for defining a model for managing unevenaged forests (Král et al. 2018). In the past, research on the quality of wood was conducted only in even-aged forests (Pretzsch and Rais 2016). However, many old trees are found in uneven-aged forests, which could provide wood of superior quality. Therefore, it is important that such trees in uneven-aged forests are studied, because the quality of wood can be the defining property that affects timber price (Zhang 1997, Macdonald et al. 2009, Höwler et al. 2019). Such research may yield results that can act as a model for silvicultural treatments (Boncina 2014), so that trees in managed forests may be developed to imitate, as far as possible, trees shaped by nature in primary forests. In addition to engendering superior timber quality, uneven-aged forest structures also ensure high biodiversity (Paraviainen 2005, Giurgiu 2013).

The research objectives of this study were: (1) to describe the relationship between the coenotic position of trees and wood quality; (2) to determine the relationship between wood quality and the ratio of diameter at breast height (DBH) to tree height; and (3) to characterise the relationship between DBH and wood quality.

\section{Study area}

\section{MATERIAL AND METHODS}

The study areas were situated in the Southern Carpathians in the Semenic, Retezat, Făgăraș, and Penteleu Mountains (Figure 1). Identification of those types of ecosystems was determined according to identification criteria of virgin forests (Korpel 1978, Leibundgut 1982). The permanent research plots (PRPs) in this study are located in protected areas (National and Natural Parks and Natura 2000 sites) and they never been directly influenced by humans.

The PRPs had an uneven-age tree structure, with a large number of trees (between 385 and 475 trees) some of which were very old (Table 1). Altitudinally, the plots were situated between $1151 \mathrm{~m}$ and $1352 \mathrm{~m}$ in the temperate continental zone, with precipitation and temperature determined by altitude and the orientation of the mountain peaks with respect to the direction of air masses.

Ambient temperature ranged from $-11^{\circ} \mathrm{C}$ (Retezat) in the winter to $16{ }^{\circ} \mathrm{C}$ in the summer (Semenic and Penteleu). 


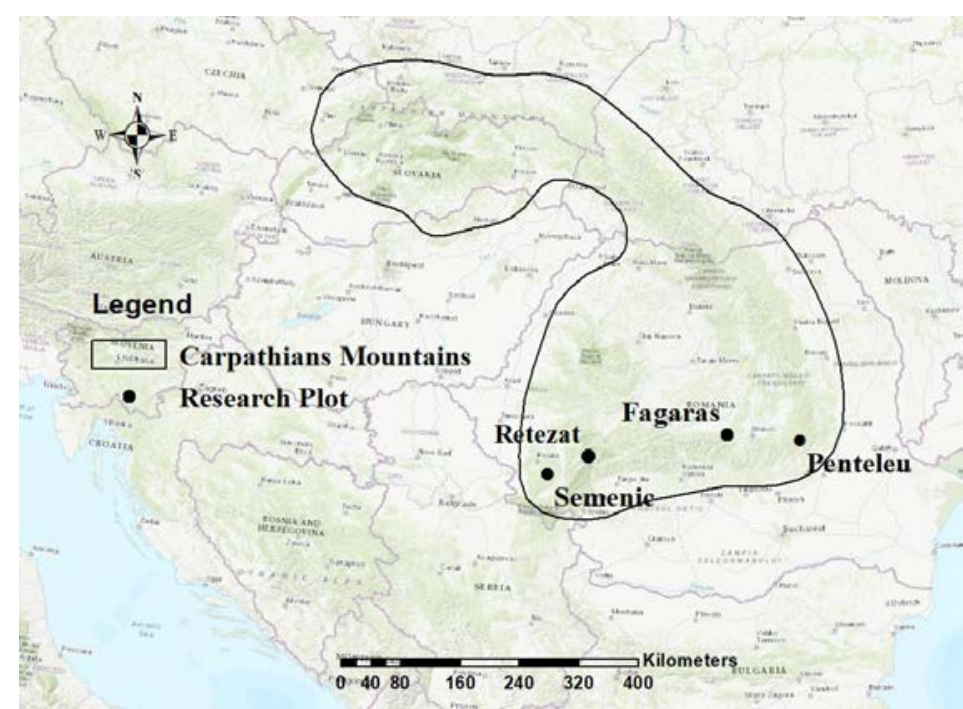

Figure 1. Location of research plots (Natural Earth 2015, Esri 2019)

Table 1. Characterisation of permanent research plots in the Southern Carpathians.

\begin{tabular}{|c|c|c|c|c|}
\hline Plot & $\begin{array}{l}\text { Geographic } \\
\text { coordinates }\end{array}$ & $\begin{array}{r}\text { Relief } \\
\text { Altitude }\end{array}$ & $\begin{array}{r}\text { Species composition } \\
\text { Production class } \\
\text { Soil type }\end{array}$ & $\begin{array}{r}\text { Number of trees } \\
\text { Area and shape } \\
\text { Volume }\end{array}$ \\
\hline Semenic & $\begin{array}{l}45^{\circ} 8 ' 25^{\prime \prime} \mathrm{E} \\
22^{\circ} 4^{\prime} 41^{\prime \prime} \mathrm{N}\end{array}$ & $\begin{array}{r}\text { Slope: } \\
26^{\circ} \\
1352 \mathrm{~m}\end{array}$ & $\begin{array}{r}100 \% \text { beech } \\
\text { Superior } \\
\text { Dystric cambisol }\end{array}$ & $\begin{array}{r}385 \\
1 \text { hectare } \\
(\text { circular) } \\
677 \mathrm{~m}^{3}\end{array}$ \\
\hline Retezat & \begin{tabular}{|c|}
$45^{\circ} 22^{\prime} 32^{\prime \prime} \mathrm{E}$ \\
$22^{\circ} 46^{\prime} 40^{\prime \prime} \mathrm{N}$
\end{tabular} & $\begin{array}{r}\text { Slope: } \\
42^{\circ} \\
1151 \mathrm{~m}\end{array}$ & $\begin{array}{r}45 \% \text { beech, } 29 \% \\
\text { spruce, } 4 \% \text { fir, } 22 \% \\
\text { hardwood } \\
\text { Middle } \\
\text { Dystric leptosol } \\
\end{array}$ & $\begin{array}{r}413 \\
1 \text { hectare } \\
\text { (rectangle) } \\
869 \mathrm{~m}^{3}\end{array}$ \\
\hline Găgăraș & \begin{tabular}{|r}
$45^{\circ} 39^{\prime} 40^{\prime \prime} \mathrm{E}$ \\
$25^{\circ} 10^{\prime} 2^{\prime \prime} \mathrm{N}$
\end{tabular} & $\begin{array}{r}\text { Slope: } \\
40^{\circ} \\
1214 \mathrm{~m}\end{array}$ & $\begin{array}{r}45 \% \text { beech, } 55 \% \text { fir } \\
\text { Superior } \\
\text { Eutric cambisol }\end{array}$ & $\begin{array}{r}475 \\
1 \text { hectare } \\
(\text { circular) } \\
758 \mathrm{~m}^{3} \\
\end{array}$ \\
\hline Penteleu & $\begin{array}{l}45^{\circ} 36^{\prime} 43^{\prime \prime} \mathrm{E} \\
26^{\circ} 25^{\prime} 47^{\prime \prime} \mathrm{N}\end{array}$ & $\begin{array}{r}\text { Slope: } \\
36^{\circ} \\
1128 \mathrm{~m}\end{array}$ & $\begin{array}{r}40 \% \text { fir, } 30 \% \text { beech, } \\
30 \% \text { spruce } \\
\text { Superior } \\
\text { Eutric cambisol } \\
\end{array}$ & $\begin{array}{r}439 \\
1 \text { hectare } \\
(\text { circular) } \\
803 \mathrm{~m}^{3} \\
\end{array}$ \\
\hline
\end{tabular}




\section{Field sampling and analyses}

Each research plot had a surface area of 1 ha; three of the plots were circular (Semenic, Făgăraș, and Penteleu) and one was rectangular (Retezat) in shape. All the trees in the research plots (with DBH higher than $7 \mathrm{~cm}$ ) were inventoried and the following tree characteristics were collected: DBH, height, species, wood quality, and coenotic position. For the diameter measurement was used a measuring tape and the height was measured with the Vertex IV hypsometer. The coenotic position was estimated by field observations.

Statistical analysis was conducted using the 'psych' package (Revelle, 2017) in R software (R Core Team, 2018), and the plot package in $\mathrm{R}$ software was used for graphical representation of the data. Volume was established for each individual tree using the equation:

$$
\log \mathrm{v}=\mathrm{a}_{0}+\mathrm{a}_{1} \log \mathrm{d}+\mathrm{a}_{2} \log ^{2} \mathrm{~d}+\mathrm{a}_{3} \log \mathrm{h}+\mathrm{a}_{4} \log ^{2} \mathrm{~h} \text {, }
$$

where $\mathrm{d}$ is $\mathrm{DBH}(\mathrm{cm}), \mathrm{h}$ is height $(\mathrm{m})$, and $\mathrm{a}_{0}, \ldots, \mathrm{a}_{4}$ are the regression coefficients (spruce: $\mathrm{a}_{0}=-4.18161, \mathrm{a}_{1}=2.08131, \mathrm{a}_{2}=$ $-0.11819, \mathrm{a}_{3}=0.70119, \mathrm{a}_{4}=0.148181 ;$ beech: $\mathrm{a}_{0}=-4.11122, \mathrm{a}_{1}=$ 1.30216, $\mathrm{a}_{2}=0.23636, \mathrm{a}_{3}=1.26562, \mathrm{a}_{4}=-0.079661$; fir: $\mathrm{a}_{0}=-4.46414$, $\left.\mathrm{a}_{1}=2.19479, \mathrm{a}_{2}=-0.12498, \mathrm{a}_{3}=1.04645, \mathrm{a}_{4}=-0.016848\right)$ established for the most important species in Romanian forests (Giurgiu et al. 2004).

The methodology for determining the quality of the wood involved estimating the proportion of wood defects (stem and crown attributes) relative to the total height of the tree, according to the type of species (softwood or hardwood; Giurgiu 2004). Stem shape defects were stem eccentricity, taper, and slenderness, and crown defects were crown diameter, length, and eccentricity.

\section{RESULTS AND DISCUSSION}

Previous studies have identified a significant relationship between stand structure and wood quality, represented by stem and crown attributes (Pretzsch and Rais 2016). Most importantly, for accurate results, these attributes have to be measurable (Pretzsch and Rais 2016). Compared to trees in even-aged forests, those in uneven-aged and primary forests have a greater capacity for growth (Pretzsch and Schütze 2009, Pretzsch et al. 2010, 2015, Metz et al. 2013, Höwler et al. 2019) due to intra- and interspecific competition, resulting in higher quality wood (Pretzsch and Rais 2016).

In this study, the PRPs contained enough trees to provide sufficient data for statistical analysis (Table 2) and ensure homogeneity of data. The number of trees varied between 385 and 475, higher than the average of 347 trees per hectare found in other studies (Curovic et al 2013). The 
volume of the trees had values between $677 \mathrm{~m}^{3}$ and $869 \mathrm{~m}^{3}$ per hectare, which corresponds to the average values $\left(796 \mathrm{~m}^{3}\right.$ per hectare) found in other virgin forests of the Eastern Carpathians and the Dinaric Alps (Keeton et al 2010, Curovic et al 2013).

Most of the trees had high quality wood, with the values falling in the upper quality classes. The wood quality values ranged between 1.80 and 2.26, and were normally distributed, with skewness close to 0 in all but one PRP. For Semenic PRP, skewness was 1.05, which only slightly exceeded 1, which is the threshold value for non-normal distribution (Hair et al. 2017).

Table 2. Statistical parameters of wood quality. Wood quality was determined as the proportion of wood defects in the stem and crown relative to the total height of the tree. Stem shape defects were stem eccentricity, taper, and slenderness, and crown defects were crown diameter, length, and eccentricity.

\begin{tabular}{|c|c|c|c|c|c|c|c|}
\hline $\begin{array}{c}\text { Research } \\
\text { plot }\end{array}$ & $\begin{array}{c}\text { Number } \\
\text { of } \\
\text { trees }\end{array}$ & Mean & S.D. & Min & Max & Skewness & Kurtosis \\
\hline Semenic & 385 & 1.80 & 0.95 & 1 & 4 & 1.05 & 0.14 \\
\hline Retezat & 413 & 1.90 & 0.93 & 1 & 4 & 0.21 & -1.80 \\
\hline Făgăraș & 475 & 2.26 & 0.92 & 1 & 4 & 0.30 & -0.74 \\
\hline Penteleu & 439 & 2.01 & 0.97 & 1 & 4 & 0.53 & -0.81 \\
\hline
\end{tabular}

\section{Wood quality in relation to stand distribution}

Based on of the properties of sawn timber, trees from the PRPs were classified into four main classes: class 1included trees with the highest quality wood (those with the fewest defects) and class 4 included trees with the lowest quality wood (with many defects in stem and crown attributes), with classes 2 and 3 being intermediate in quality (Fig. 2).

Most trees in most of the plots were in classes 1 and 2 (tending towards superior wood quality) with fewer defects, except for the trees in the Retezat PRP, which were in classes 2 and 3. Other research, in those types of forests, indicate that the site class and site index not always have a good correlation (Curovic et al. 2011*) but in this case they have. Although previous research in managed forests have shown that wood quality declines with tree age (Guiman, 2007), this was not the case for trees in our plots. Our results suggest that natural selection may have resulted in the survival of trees with high-quality wood, and identification of selective pressures may provide solutions for forest management that could lead to stands with superior wood quality. 

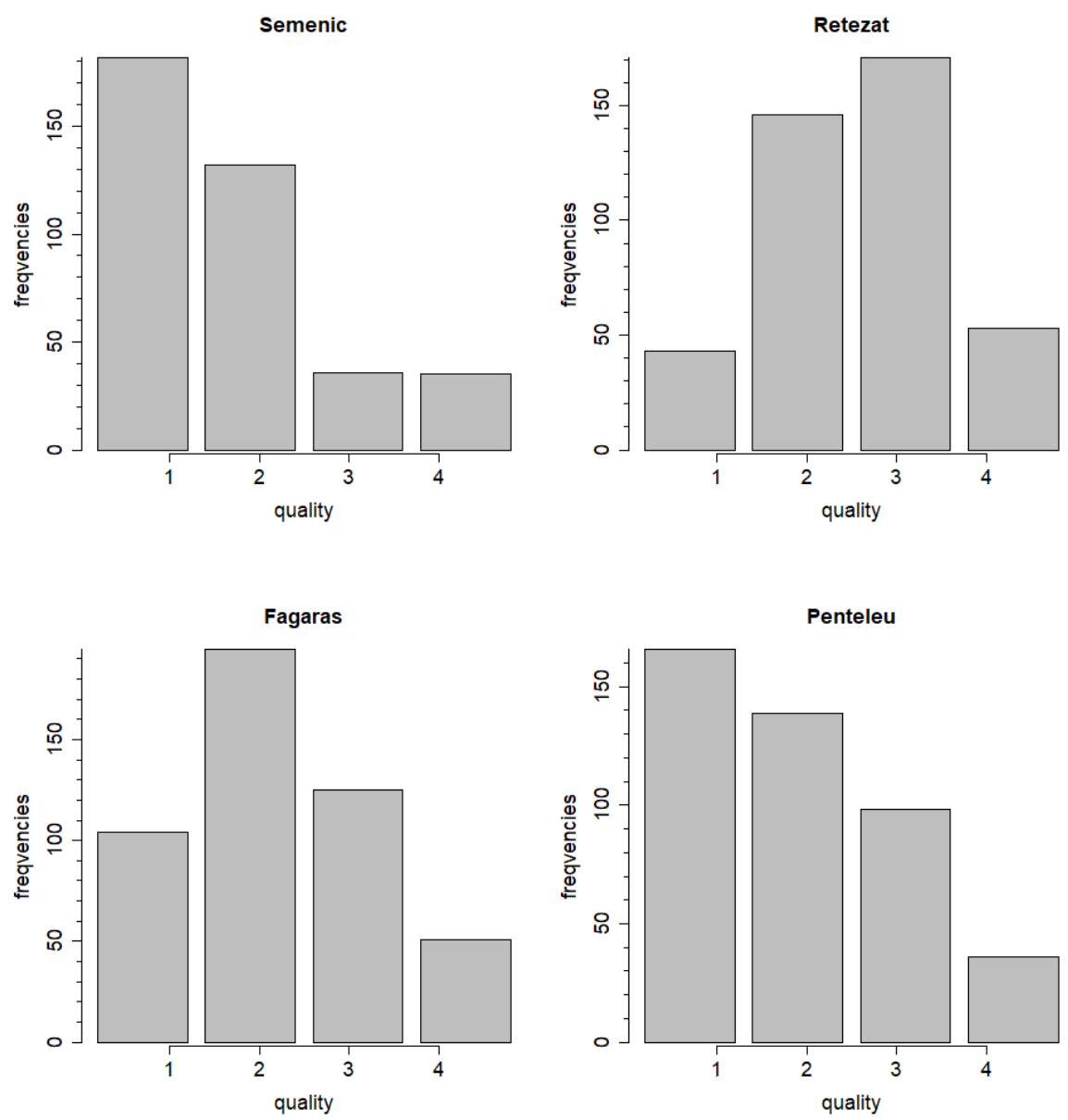

Figure 2. Frequency trees in relation to wood quality.

\section{Relationship between wood quality and coenotic position}

In uneven-aged forests and primary forests, tree stands can be characterised in relation to coenotic position as follows: inferior floor (where suppressed trees are found); middle floor (where codominant trees are found); and superior floor (where the dominant trees are found). In this study, there was a strong relationship between wood quality and coenotic position, with high correlation coefficients (r) ranging from $0.89 *$ to $0.99 * * *$ (Fig. 3).

Our results also showed that the quality of wood was higher in the first coenotic floor and lower in the third coenotic floor in all research plots. The wood quality in all the plots was very high, with the highest identified in the Semenic PRP (1.27) and the lowest in Retezat Zănoaga (2.65).

The shape of the stem is a good indicator of the predisposition of trees to windthrow and snow-throw (Wilson and Oliver 2000, Harrington et al. 2009); stem shape is influenced by silvicultural treatment (Brazier, 
1977) and coenotic position (Bruchert et al 2000). Our results show that the stands in the PRPs are stable and appear to be able to withstand uprooting by wind or snow.
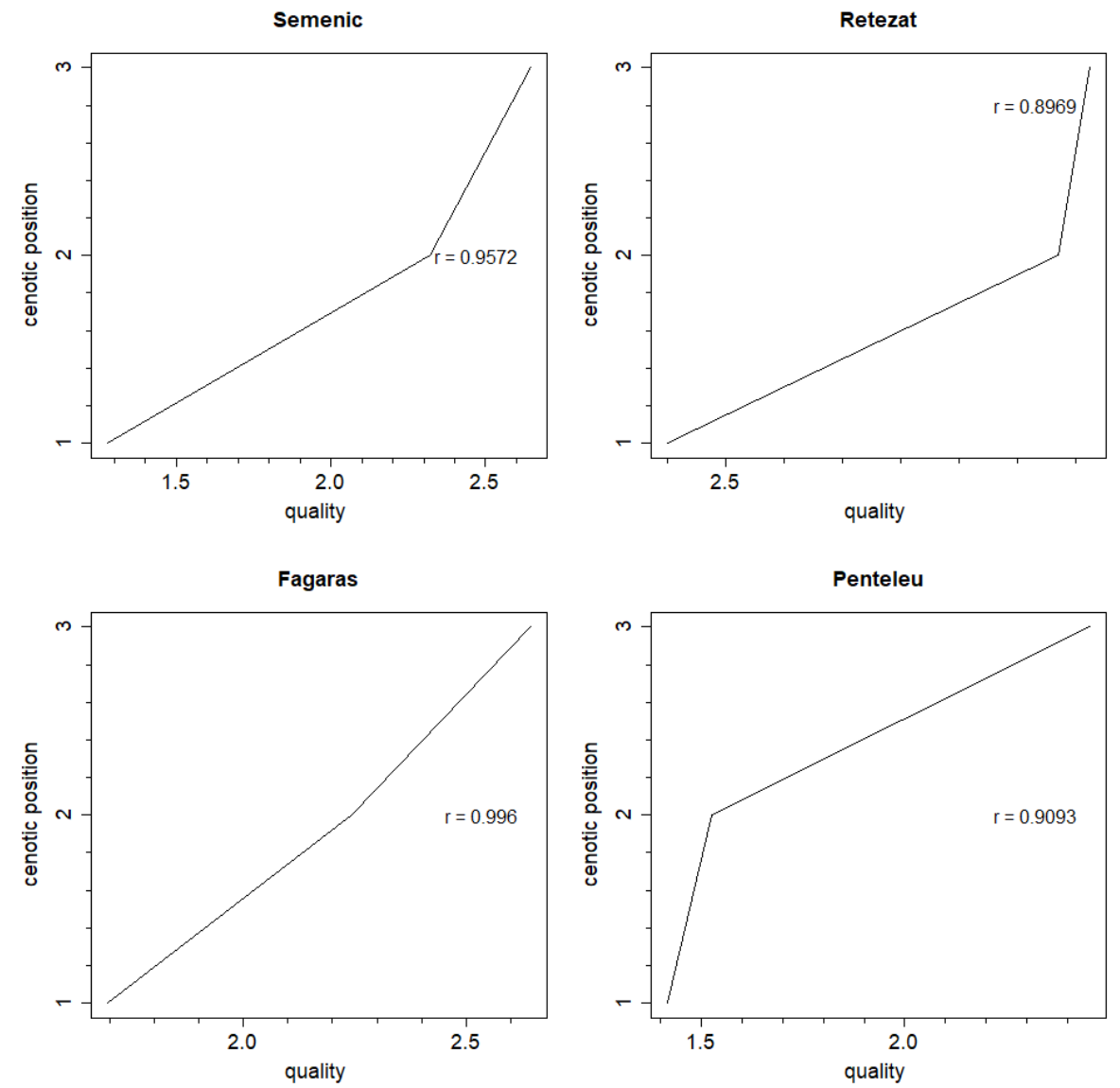

Figure 3. The relationship between wood quality and the coenotic position of trees.

Given the relationship between wood quality and coenotic position, the latter could be used as an indicator in forest management; stand quality could be determined by simply identifying the coenotic position of trees, without having to measure tree parameters relating to quality.

\section{wood quality}

Relationship between slenderness (the height-to-diameter ratio) and

Many studies have shown that stem shape is a good indicator of wood quality both for individual trees and for entire stands (Roth et al. 2007, Lasserre et al. 2009, Lindstrom et al. 2009, Lenz et al. 2012, Searles 2012, Pretzsch and Rais 2016). It is important to use indicators that are easy to measure; one such is 
the height-to-diameter ratio or slenderness (Pretzsch and Rais 2016), which has yielded good results for predicting wood quality in previous studies (Reukema and Smith 1987, Kijidani et al. 2009, Lindstrom et al. 2009). In our study, there was a strong correlation between wood quality and slenderness (Fig. 4), with correlation coefficients ranging between 0.56 (Retezat) and $0.95^{* * *}$ (Făgăraș).
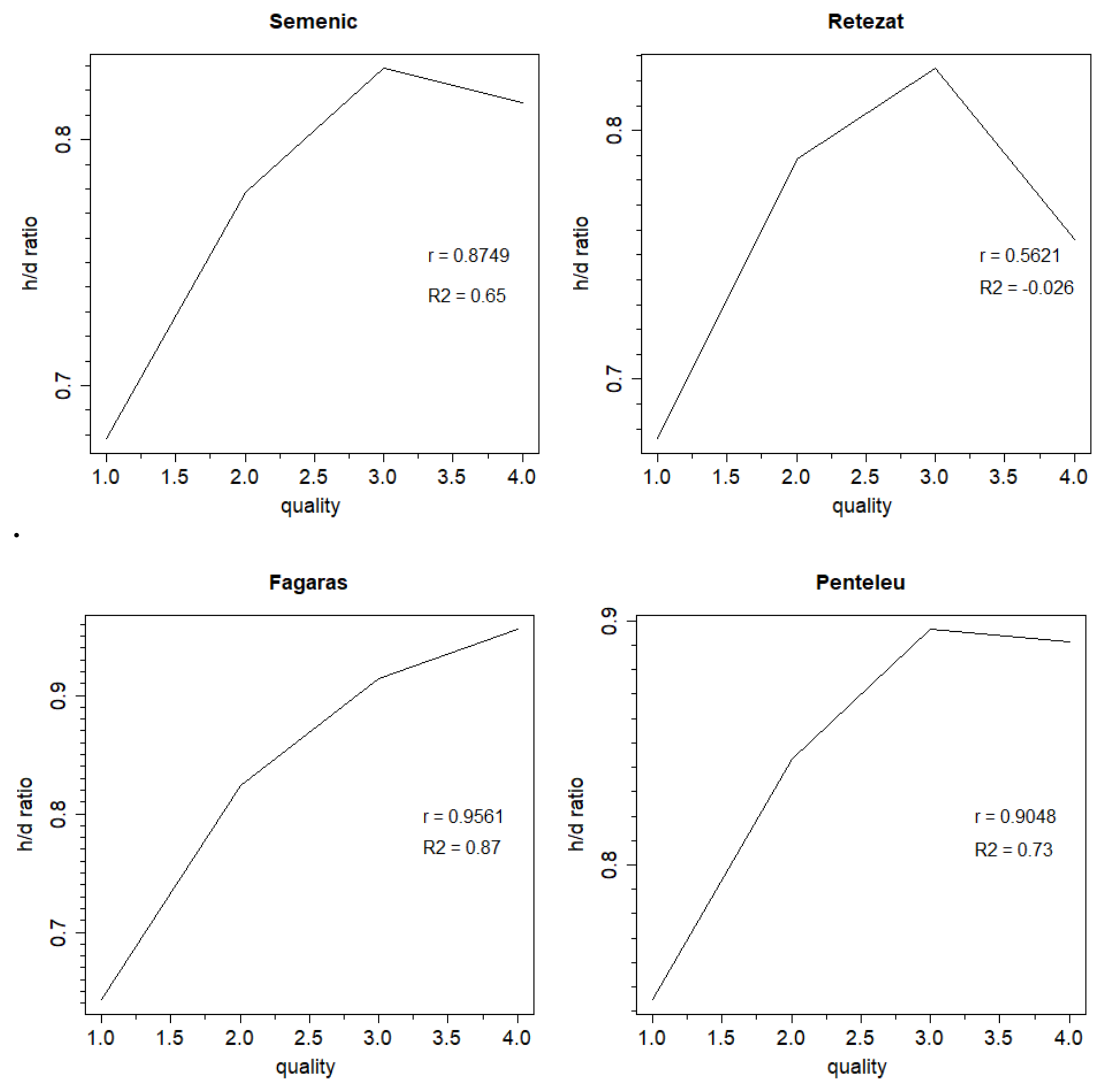

Figure 4. The relationship between wood quality and slenderness of trees.

Another aspect highlighted in this study was that the loss of wood quality was greater as slenderness increased; the slenderness index for class 1 (superior) of wood quality was about 0.7 , whereas it was $0.8-0.9$ for class 4 (inferior) of wood quality. All PRPs except Retezat had strong correlations between slenderness index and wood quality.

Similar results have been obtained in other studies $\left(r^{2}=0.52\right.$; Pretzsch and Rais 2016). In the case of Retezat PRP, the number of trees with lower quality wood was high, which may have resulted in a weaker relationship between slenderness and wood quality. 


\section{Relationship between DBH and wood quality}

The wood quality of the stand is determined by every individual tree within the stand, and the wood quality of individual trees is influenced by the degree of competition with surrounding trees and by silvicultural treatment (Zingg and Ramp 2003, Höwler et al. 2017). Characteristics of wood quality that can be influenced by silvicultural treatment are DBH, size and abundance of knots, crown development, stem curvature, and the proportion of juvenile wood (Hein 2008 van Leeuwen et al. 2011, Richter 2015). Among these characteristics, DBH and knottiness have the highest influence on wood quality and timber price (Ammer, 2016). Figure 5 shows a relatively stable relationship between DBH and wood quality, in which juvenile trees are found in lower wood-quality classes. This strong relationship was highlighted by statistically significant correlation coefficients ( $\mathrm{r}$ semenic $=-0.66^{* * *}, \mathrm{r}$ Penteleu $=-0.59^{* * *}$ ), except for Retezat $\left(r=0.25^{*}\right)$ and Făgăraș $(r=-0.32 * * *)$ PRPs where the correlations were weak.
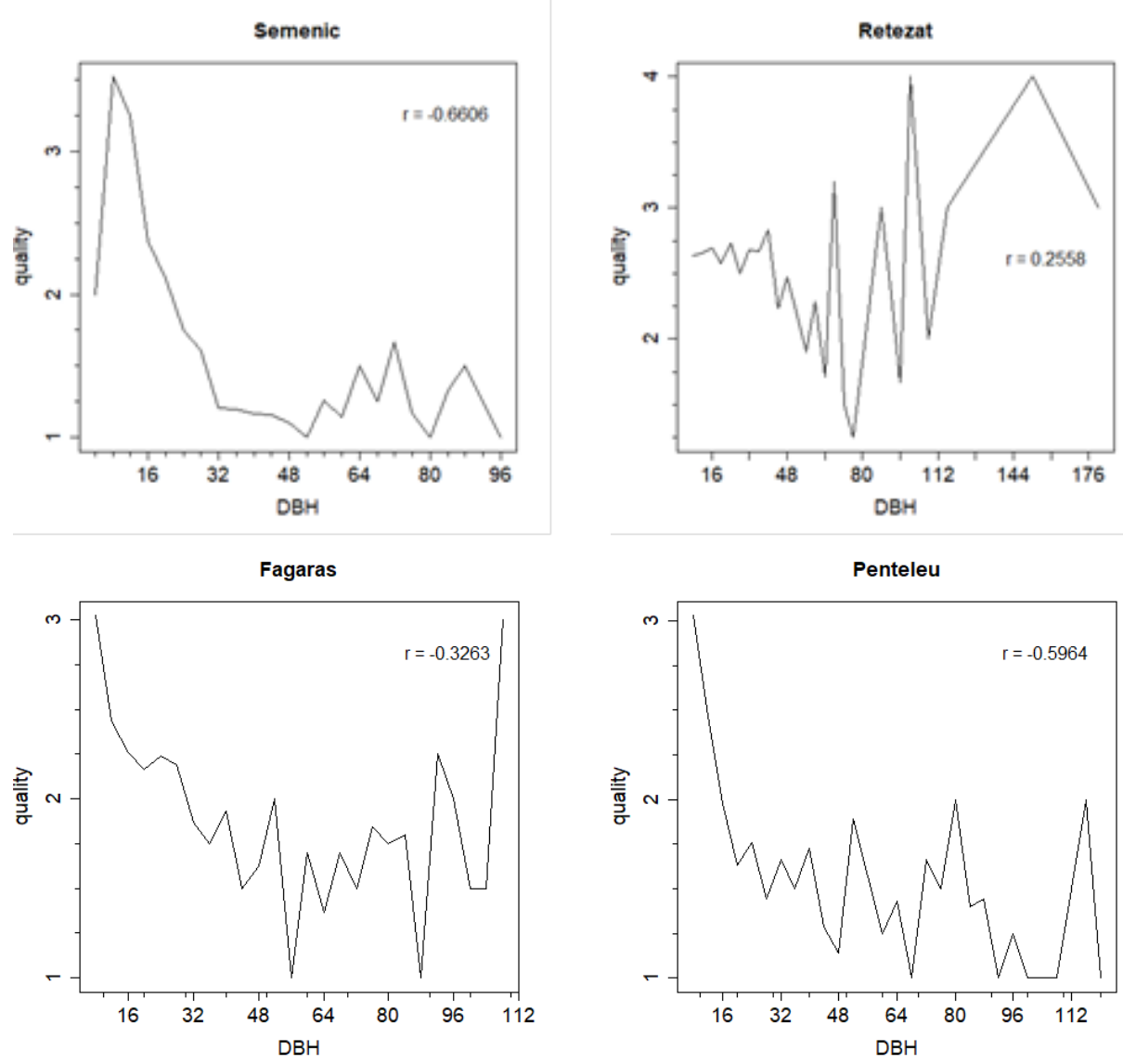

Figure 5. The relationship between wood quality and DBH of trees. 
In all the plots, the DBH of trees with the highest quality wood ranged between $30 \mathrm{~cm}$ and $100 \mathrm{~cm}$; this range is wider than the that found in other studies (e.g. 30-40 cm; Prestemon and Buongiorno 2000). The diameter limit for selective cutting, according to production class, in Romanian forests is set at 48$100 \mathrm{~cm}$ (MWFEP 2000, Chișca et al. 2018); our results confirm that this range is appropriate for identifying trees with higher quality wood.

\section{CONCLUSIONS}

Due to environmental changes and the impact of anthropogenic pressures, research on primary forests has intensified. Primary forests represent a worthy model for management and structuring of managed forests. In this study, we investigated aspects of wood quality in primary forests located in the Southern Carpathians to develop solutions for selected treatment of uneven-aged forests.

The statistical analysis highlighted that the wood quality of stands in most of the PRPs was normally distributed. In addition, most of the trees were found in wood quality classes 1 and 2 (superior wood quality) with fewer defects, except in the Retezat PRP where most of the trees were in quality classes 2 and 3 (intermediate quality). This suggests that natural selection may lead to better stand quality than silvicultural treatment.

The relationship between wood quality and coenotic position was strong, with statistically significant correlation coefficients. Trees from the first coenotic floor had higher quality wood than trees from the third coenotic floor. Therefore, the coenotic position of the tree could be used as an indicator for predicting the quality of its wood without measuring it for wood parameters. The relationship between slenderness and wood quality was also shown to be strong, with wood quality increasing as slenderness decreased.

Because the price of timber depends on the quality of the wood, it is important to design a simple methodology for quickly determining wood quality without having to take too many measurements. Our study found a strong correlation between DBH and wood quality; the $\mathrm{DBH}$ of trees with the highest quality wood ranged between $30 \mathrm{~cm}$ and $100 \mathrm{~cm}$.

Uneven-aged forests are superior than even-aged forests because they provide greater stability, continuity, and protection for trees. In addition, they provide higher quality wood and a greater quantity of timber. Therefore, it is necessary for modern forestry to follow the model that nature offers in primary forests by imitating their actions in managed forests.

\section{REFERENCES}

Ammer C (2016): Starkholz-wertvolles Instrument der waldbaulichen Steuerung. AFZ/Der Wald 71:33-36

Bândiu, C., Smejkal, G. M., \& Vişoiu-Smejkal, D. (1995): Pădurea seculară. Cercetări ecologice în Banat, Editura Mirton, Timişoara. 
Boncina, A., Cavlovic, J., Curovic, M., Govedar, Z., Klopcic, M. and Medarević, M.(2014): A comparative analysis of recent changes in Dinaric uneven-aged forests of the NW Balkans, Forestry, Volume 87 Issue 1, pp. 71-84, DOI: 10.1093/forestry/cpt038

Brazier JD (1977): The effect of forest practices on quality of the harvested crop. Forestry 50(1):49-66

Bruuhert F, Becker G, Speck T (2000): The mechanics of Norway spruce [Picea abies (L.) Karst]: mechanical properties of standing trees from different thinning regimes. For Ecol Manag 135(1-3):45-62

CICŞA, A., Tudoran, M.T, DOBRE, A. C., Mihăilă, V.V., MIHAI, R. G., Mărgălinescu, A.M., Farcaș, C.Ș., Comaniță, I., Boroeanu, M.(2018): Structure models for beech-conifers stands with protective functions. Proceedings of the Biennial International Symposium ”Forest and Sustainable Development”8thEdition, 25th27thof October 2018, Brașov, Romania

Curovic, M., Medarevic, M., Pantic, D., Spalevic, V.(2011): Major types of mixed forests of spruce, fir and beech in Montenegro; Austrian Journal of Forest Science, Vol. 128, Heft 2; p. 93-111, ISSN: 0379-5292

Curovic M., Stesevic, D., Medarevic, M., Cvjeticanin, R., Pantic, D., Spalević, V (2011*): Ecological and structural characteristics of monodominant montane beech forests in the national park Biogradska Gora-Montenegro, Archives of biological sciences, 63 (2) pp:429-440, ISSN: 0354-4664. eISSN: 1821-4339

Curovic M., Spalevic V. and Medarevic M. (2013): The ratio between the real and theoretically normal number of trees in mixed fir, beech and spruce forests in the national park "Biogradska Gora”. Agriculture \& Forestry, Vol. 59. Issue 1: 7-17, ISSN 0554-5579

ESRI (2019): World Topographic Map - Sources: Esri, HERE, DeLorme, Intermap,increment P Corp., GEBCO, USGS, FAO, NPS, NRCAN, GeoBase, IGN, Kadaster NL, Ordnance Survey, Esri Japan, METI, Esri China (Hong Kong), swisstopo, MapmyIndia, (C) OpenStreetMap contributors, and the GIS User Community.

Giurgiu V., Decei I., Drăghiciu D. (2004): Metode și tabele dendrometrice. București, Editura Ceres: 575.

Giurgiu, V. (editor) (2013): Pădurile virgine și cvasivirgine ale României, Ed. Academiei Române, 390 p.

Guiman, G. (2007): Optimizarea structurii arboretelor prin aplicarea tratamentului codrului grădinărit în făgete din Bazinul Mijlociu și Superior al Argeșului, Teză de doctorat, Universitatea Ștefan cel Mare, Suceava, 225p.

Hair, J. F., Hult, G. T. M., Ringle, C. M., and Sarstedt, M. (2017): A Primer on Partial Least Squares Structural Equation Modeling (PLS-SEM). 2nd Ed. Thousand Oaks, CA: Sage

Harrington TB, Harrington CA, DeBell DS (2009): Effects of planting spacing and site quality on 25-year growth and mortality relationships of Douglas-fir (Pseudotsuga menziesii var. menziesii). For Ecol Manag 258(1):18-25

Hein S (2008): Knot attributes and occlusion of naturally pruned branches of Fagus sylvatica. For Ecol Manag 256:2046-2057

Höwler K, Annighöfer P, Ammer C, Seidel D (2017): Competition improves qualityrelated external stem characteristics of Fagus sylvatica. Can J For Res 47:16031613

Höwler, K., Annighöfer, P., Ammer, C., \& Seidel, D. (2017). Competition improves quality-related external stem characteristics of Fagus sylvatica. Canadian Journal of Forest Research, 47(12), 1603-1613. 
Keeton, W. S.,Chernyavskyy, M., Gratzer, G., Main-Knorn, M., Shpylchak, M., Bihunf, Y.(2010): Structural characteristics and aboveground biomass of old-growth spruce fir stands in the eastern Carpathian mountains, Ukraine; Plant Biosystems, 144 (1): 148-159

Kijidani Y, Hamazuna T, Ito S, Kitahara R, Fukuchi S, Mizoue N, Yoshida S (2009): Effect of height-todiameter ratio on stem stiffness of sugi (Cryptomeria japonica) cultivars. J Wood Sci 56(1):1-6

Korpel Š (1978): Obnova lesnych porastov v rubáòovom sposobe hospodárenia [Restoration of forest stands in the ruby way of management]. [W:] Pesteni lesù. (red. M. Vyskot M.), SZN, Praha: 216-359 [in slovakian].

Král K, Daněk P, Janík D, Krůček M, Vrška T (2018): How cyclical and predictable are Central European temperate forest dynamics in terms of development phases?. Journal of vegetation science, 29(1), 84-97. doi: 10.1111/jvs.12590

Lasserre JP, Mason EG, Watt MS, Moore JR (2009): Influence of initial planting spacing and genotype on microfibril angle, wood density, fibre properties and modulus of elasticity in Pinus radiata D. Doncorewood. For Ecol Manag 258(9):1924-1931

Leibundgut H. (1982): Europäische Urwälder der Bergstufe: dargestellt für Forstleute,

Naturwissenschafter und Freunde des Waldes [European primeval forests of the Bergstufe: represented for foresters, Naturalists and friends of the forest]. Bern, Stuttgart, Haupt. 308 pp. [in german]

Lenz P, Bernier-Cardou M, MacKay J, Beaulieu J (2012): Can wood properties be predicted from the morphological traits of a tree? A canonical correlation study of plantation-grown white spruce. Can J For Res 42(8):1518-1529

Lindstrom H, Reale M, Grekin M (2009): Using non-destructive testing to assess modulus of elasticity of Pinus sylvestris trees. Scand J For Res 24(3):247-257

Macdonald, E., Gardiner, B., \& Mason, W. (2009): The effects of transformation of evenaged stands to continuous cover forestry on conifer log quality and wood properties in the UK. Forestry, 83(1), 1-16

Metz J, Seidel D, Schall P, Scheffer D, Schulze E-D, Ammer C (2013) Crown modeling by terrestrial laser scanning as an approach to assess the effect of aboveground intra- and interspecific competition on tree growth. For Ecol Manag 310:275-288

Natural Earth (2015): Area and point labels of major physical features, Physical vectors, www.naturalearthdata.com

Parviainen J (2005): Virgin and natural forests in the temperate zone of Europe. For. Snow Landsc. Res,18: 9-18.

Prestemon, J. P., \& Buongiorno, J. (2000): Determinants of tree quality and lumber value in natural uneven-aged southern pine stands. Canadian journal of forest research, 30(2), 211-219.

Pretzsch, H., \& Rais, A. (2016): Wood quality in complex forests versus even-aged monocultures: review and perspectives. Wood science and technology, 50(4), 845880.Pretzsch and Schütze 2009;

Pretzsch H, Block J, Dieler J, Dong PH, Kohnle U, Nagel J, Spellmann H, Zingg A (2010) Comparison between the productivity of pure and mixed stands of Norway spruce and European beech along an ecological gradient. Ann For Sci 67:712

Pretzsch H, Forrester DI, Rotzer Th (2015): Representation of species mixing in forest growth models. A Rev Perspect. Ecol model 313:276-292

R Core Team (2018) R: A language and environment for statistical computing. R Foundation for Statistical Computing, Vienna

Reininger, H. (1997): Pădurea seculară românească, arhetip pentru a silvicultură pe baze ecologice, Revista Pădurilor, nr.4, pp. 92-94. 
Reukema DL, Smith JHG (1987): Development over 25 years of Douglas-fir, western hemlock, andwestern red cedar planted at various spacings on a very good site in British Columbia. USDA For Serv Res Pap PNW-RP- 381:46

Revelle, W. R. (2017): psych: Procedures for personality and psychological research.

Richter C (2015): Wood characteristics: description, causes, prevention, impact on use and technological adaptation. Springer, Cham

Romanian Ministry of Waters, Forests and Environmental Protection (2000): Norme tehnice pentru amenajarea pădurilor (5)

Roth BE, Li X, Huber DA, Peter GF (2007): Effects of management intensity, genetics and planting density on wood stiffness in a plantation of juvenile loblolly pine in the southeastern USA. For Ecol Manag 246(2-3):155-162

Searles GJ (2012): Acoustic segregation and structural timber production. PhD thesis, Edinburgh Napier

Stoiculescu, C. (2013): Făgetele virgine din România în context european sub influinţa schimbărilor climatice.

van Leeuwen M, Hilker T, Coops NC, Frazer G, Wulder MA, Newnham GJ, Culvenor DS (2011): Assessment of standing wood and fiber quality using ground and airborne laser scanning: a review. For Ecol Manag 261:1467-1478. https://doi.org/10.1016/j.foreco.2011.01.032

Wilson JS, Oliver CD (2000): Stability and density management in Douglas-fir plantations. Can J For Res 30(6):910-920

Zhang , S.Y. (1997): Wood quality: its defi nition, impact and implications for valueadded timber management and end uses. Part I: its defi nition and impact . In Timber Management Toward Wood Quality and End-Product Value . S.Y. Zhang , R. Gosselin and G. Chauret (eds). Proceedings of the CTIA/IUFRO International Wood Quality Workshop, Quebec City , pp. 17 - 39 .

Zingg A, Ramp B (2003): Wachstum und Stammqualität in reinen und gemischten Buchenbeständen. Tagungsbericht, Jahrestagung 1997 des Deutschen Verbandes Forstlicher Forschungsanstalten 152-164 